\title{
Allometric equations for estimating tree biomass in restored mixed-species Atlantic Forest stands
}

\author{
Lauro Rodrigues Nogueira Junior ${ }^{1,5}$, Vera Lex Engel ${ }^{2}$, John A. Parrotta ${ }^{3}$, Antonio Carlos Galvão de Melo ${ }^{4}$ \\ \& Danilo Scorzoni $\boldsymbol{R e}^{2}$ \\ ${ }^{1}$ Empresa Brasileira de Pesquisa Agropecuária (Embrapa), Caixa Postal 44, CEP 49025-040, Aracaju, SE, \\ Brasil. www.cpatc.embrapa.br \\ ${ }^{2}$ Universidade Estadual Paulista "Julio de Mesquita Filho" (UNESP), Faculdade de Ciências \\ Agronômicas, Departamento de Ciências Florestais, Caixa Postal 237, CEP 18610-307, Botucatu, SP, \\ Brasil. www.fca.unesp.br \\ ${ }^{3}$ USDA Forest Service, Research \& Development, 1601 N. Kent Street, Arlington VA 22209, USA. \\ www.fs.fed.us/research/ \\ ${ }^{4}$ Instituto Florestal de São Paulo (IF-SP), Floresta Estadual de Assis, Caixa Postal 104, CEP 19802-300, \\ Assis, SP, Brasil. www.iflorestal.sp.gov.br \\ ${ }^{5}$ Corresponding author: e-mail: lauro.nogueira@embrapa.br
}

NOGUEIRA JUNIOR, L.R., ENGEL, V.L., PARROTTA, J.A., MELO, A.C.G., RÉ, D.S. Allometric equations for estimating tree biomass in restored mixed-species Atlantic Forest stands. Biota Neotropica. 14(2): e20130084. http://dx.doi.org/10.1590/1676-06032013008413

\begin{abstract}
Restoration of Atlantic Forests is receiving increasing attention because of its role in both biodiversity conservation and carbon sequestration for global climate change mitigation. This study was carried out in an Atlantic Forest restoration project in the south-central region of São Paulo State Brazil to develop allometric equations to estimate tree biomass of indigenous tree species in mixed plantations. Above and below-ground biomass (AGB and BGB, respectively), stem diameter (DBH: diameter at $1.3 \mathrm{~m}$ height), tree height ( $\mathrm{H}$ : total height) and specific wood density (WD) were measured for 60 trees of 19 species. Different biomass equations (linear and nonlinear-transformed) were adjusted to estimate $\mathrm{AGB}$ and $\mathrm{BGB}$ as a function of $\mathrm{DBH}, \mathrm{H}$ and WD. For estimating AGB and BGB, the linear biomass equation models were the least accurate. The transformed nonlinear biomass equation that used $\log \mathrm{DBH}^{2}, \log \mathrm{H}$ and $\log \mathrm{WD}$ as predictor variables were the most accurate for AGB and the transformed nonlinear biomass equations that used $\log \mathrm{DBH}^{2 *} \mathrm{WD}$ as predictor variables were the most accurate for BGB. It is concluded that these adjusted equations can be used to estimate the AGB and BGB in areas of the studied project. The adjusted equations can be recommended for use elsewhere in the region for forest stands of similar age, tree size ranges, species composition and site characteristics.
\end{abstract}

Keywords: Above-ground biomass, Below-ground biomass, Biomass equation, Tree allometry, Atlantic Forest, Restoration.

NOGUEIRA JUNIOR, L.R., ENGEL, V.L., PARROTTA, J.A., MELO, A.C.G., RÉ, D.S. Equações alométricas para estimativa da biomassa arbórea em plantios mistos com espécies nativas na restauração da Mata Atlântica. Biota Neotropica. 14(2): e20130084. http://dx.doi.org/10.1590/1676-06032013008413

Resumo: A restauração da Mata Atlântica vem recebendo aumento na atenção por causa do papel na conservação da biodiversidade e sequestro de carbono para a mitigação da mudança global do clima. Este estudo foi conduzido em um projeto de restauração da Mata Atlântica na região centro-sul do Estado de São Paulo - Brasil e buscou desenvolver equações alométricas para estimar a biomassa arbórea de espécies nativas em plantios mistos. Em 60 árvores de 19 espécies foram medidas a biomassa acima e abaixo do solo, o diâmetro do tronco (DAP: diâmetro a $1,3 \mathrm{~m}$ de altura), altura $(\mathrm{H})$ e densidade específica da madeira (Ds). Diferentes equações de biomassa (linear e não linear) foram ajustadas para estimar a biomassa acima e abaixo do solo, utilizando DAP, H e Ds como variáveis preditoras. As equações de biomassa lineares foram as menos acuradas para a estimativa da biomassa acima e abaixo do solo. As equações de biomassa não lineares que usaram $\log \mathrm{DAP}^{2}, \log \mathrm{H}$ e $\log \mathrm{Ds}$ como variáveis preditoras foram mais acuradas para a estimativa da biomassa acima do solo e as não lineares que usaram $\log \mathrm{DBH}^{2 *} \mathrm{WD}$ como variáveis preditoras foram as mais acuradas para a estimativa da biomassa abaixo do solo. Conclui-se que estas equações ajustadas podem ser usadas na estimativa da biomassa acima e abaixo do solo nas áreas do projeto estudado. Também pode ser considerado o uso destas 
equações ajustadas em outras áreas restauradas da Mata Atlântica com idade do povoamento, classes de tamanho das árvores, composição de espécies e características das áreas similares ao deste estudo, desde que árvores sejam avaliadas para verificar a eficácia da equação a ser usada.

Palavras-chave: Biomassa acima do solo, Biomassa abaixo do solo, Equação de biomassa, Alometria, Mata Atlântica, Restauração.

\section{Introduction}

The restoration of Brazil's Atlantic Forest on degraded lands and riparian areas is receiving increasing attention in the development of public policies for biodiversity conservation and climate change mitigation purposes, with increasing funds available for this purpose through public and private programs and international cooperation (Rodrigues et al. 2009, Rodrigues et al. 2011, Calmon et al. 2011). An area of particular interest is the capacity of these restored forests to absorb atmospheric carbon dioxide and thereby enhance their role as a carbon sink. Accurate estimates of carbon sequestration in these restored forests require development of equations for accurately estimating tree biomass in mixed native species stands.

Tree biomass is an important characteristic of forest ecosystems, reflecting the accumulation of organic carbon and ecosystem productivity (Dixon et al. 1994, Clark et al. 2001, Masera et al. 2003, Grace 2004, Lal 2005) and it can be an important indicator for monitoring the developmentof restored ecosystems (Naeem et al. 2009). Moreover, accurate tree biomass estimates permit comparisons between restored and reference sites and estimates of nutrient stocks in tree compartments of the ecosystem.

There are several indirect methods for tree biomass estimates, such as allometric equations, most of which use a combination of predictor variables such as tree stem diameter, total height and wood density (Saldarriaga et al. 1988, Brown et al. 1989, Overman et al. 1994, Brown 1997, Nelson et al. 1999, Chave et al. 2005, Cole \& Ewel 2006). According to Chave et al. (2005), the most important variables for predicting aboveground biomass are, in decreasing order of importance, tree stem diameter, woody specific density, tree height, and forest type. To select biomass equations models, the Akaike Information Criterion (AIC) provides a simple, effective and direct way to select the variables that will produce the best fitting model (Burnham \& Anderson 2010).

Multi-species biomass equations are usually based on tree data from primary forests, which usually have different tree architectures than those found in planted (restoration) forests, and typically do not estimate root biomass (Brown et al. 1989, Brown 1997, Nelson et al. 1999, Chave et al. 2005). Miranda et al. (2011) developed and fitted allometric models to estimate dry biomass in trees (including both Cerrado and Atlantic forest species) planted in forest restoration areas ranging in age between 5 and 36 years. In their work, the best results were obtained by stepwise procedures with stratification of species by growth rates. However, equations models for estimating tree biomass in multispecies restoration projects are scarce; equations obtained from trees in natural mature forests are usually used for biomass and carbon estimations in restoration projects (Melo e Durigan 2006), in spite of the differences between tree structural patterns in these two different conditions. Here, we aimed at refining allometric equations for estimating biomass of trees planted in an Atlantic Forest restoration project in Brazil, to be used to assess the role of different plantations systems as carbon sinks.

\section{Materials and Methods}

The study sites were located at the São Paulo State University (UNESP) Experimental Farm, Botucatu, south-central region of São Paulo State, Brazil (22 ${ }^{\circ} 52^{\prime} 32^{\prime \prime} \mathrm{S}$ and $\left.48^{\circ} 26^{\prime} 46^{\prime \prime} \mathrm{W}\right)$. According to Köeppen's classification the climate is Cfa. Annual rainfall averages 1,494 $\mathrm{mm}$ with the rainy season lasting from October to March. Annual mean temperature is $20.5^{\circ} \mathrm{C}$, with the minimum average occurring in July and maximum in February. The natural vegetation is a semi-deciduous tropical moist forest within the Atlantic Forest biome range.

The experiment was undertaken at two sites with Ultisol (22 $49^{\circ} 39^{\prime \prime} \mathrm{S}$ and $48^{\circ} 25^{\prime} 55^{\prime \prime} \mathrm{W}$ ) and Alfisol (22 $48^{\circ} 54^{\prime \prime} \mathrm{S}$ and $\left.48^{\circ} 24^{\prime} 56^{\prime \prime} \mathrm{W}\right)$ soils, respectively. At each site an experiment with 5 treatments and three replicates (random blocks design) was established from 1997 to1998, with each plot measuring $50 \times 50$ $\mathrm{m}$. Treatments ranged from passive restoration (control plots) to a high-diversity native tree species mixture, and included a direct seeding system, an agroforestry system and a commercial species mixture (Engel \& Parrotta 2001, Siddique et al. 2008, Nogueira Jr et al. 2011).

In 2009 we sampled 19 of the native tree species (Table 1) included in the experimental treatments (Control, Direct Seeding and High-Diversity Seedling Planting). These species represent more than $95 \%$ of the basal area in the restoration plots, based on previous inventories. They included two ecological groups (fast growing pioneer and slower growing secondary species. All selected individuals were located inside the restoration plots at least $10 \mathrm{~m}$ from the edge boundaries. Three individuals of each species, representing the range of tree sizes for each species, were sampled in the restoration treatments, by measuring diameter at breast height $(\mathrm{DBH})$ and total height $(\mathrm{H})$. Only for Psidium guajava six individuals were sampled, three in understory of Direct Seeding and High-Diversity Seedling Planting treatment and three in open area of Control treatment. For trees with more than one stem, we calculated the equivalent $\mathrm{DBH}$ :

equivalent $D B H=\sqrt{d b h 1^{2}+d b h 2^{2}+d b h 3^{2} \ldots d b h n^{2}}$

where, $\mathrm{dbh}=$ diameter at breast height of each stem

Among the trees sampled, tree heights ranged from 2.7 to $15.8 \mathrm{~m}$ and stem diameters ranged from 2 to $33 \mathrm{~cm}$ (Table 1). After being measured, each tree was felled and tree biomass was quantified by the direct method. For above-ground biomass (AGB) three compartments were considered: 1) leaves - leaves and twigs with diameters up to $1 \mathrm{~cm}$; 2) twigs/branches - woody material of crown of the tree up to a minimum diameter of $1 \mathrm{~cm}$; 3) stem - the main wooden axis of a tree, located between the base and the crown of the tree. For below-ground biomass (BGB) only roots with diameters $>1 \mathrm{~cm}$ were considered. Roots were excavated manually for small trees and with the aid of a retro bulldozer for medium and large trees.

The fresh weight of each individual tree and its components was determined in the field using a dynamometer with capacity 
Allometric equations for Atlantic Forest stands

Table 1. Diameter at breast height (DBH), height and specific wood density (WD) of each sampled tree (large (L), medium (M) and small (S)), for 19 native tree species (60 harvested trees) assessed by the direct method to quantify biomass.

\begin{tabular}{|c|c|c|c|c|c|c|c|c|c|c|}
\hline \multirow[t]{2}{*}{ Botanical Family } & \multirow[t]{2}{*}{ Species } & \multicolumn{3}{|c|}{ DBH } & \multicolumn{3}{|c|}{ Height } & \multicolumn{3}{|c|}{ WD } \\
\hline & & $\mathbf{L}$ & $\mathbf{M}$ & $\mathbf{S}$ & $\mathbf{L}$ & $\mathbf{M}$ & $\mathbf{S}$ & $\mathbf{L}$ & $\mathbf{M}$ & $\mathbf{S}$ \\
\hline & & \multicolumn{3}{|c|}{$-\mathrm{cm}$} & \multicolumn{3}{|c|}{$\mathrm{m}$} & \multicolumn{3}{|c|}{$\mathrm{g} \mathrm{cm}^{-3}$} \\
\hline Fab. Mimosoideae & $\begin{array}{l}\text { Piptadenia gonoacantha J.F. } \\
\text { Macbr. }\end{array}$ & 33.3 & 14.0 & 4.0 & 13.6 & 9.1 & 5.0 & 0.54 & 0.51 & 0.46 \\
\hline Fab. Faboideae & Schizolobium parahyba S.F. Blake & 26.1 & 19.3 & 13.1 & 15.8 & 12.1 & 11.7 & 0.29 & 0.29 & 0.25 \\
\hline Fab. Mimosoideae & Parapiptadenia rigida Brenan & 25.8 & 13.1 & 7.0 & 7.1 & 7.2 & 5.9 & 0.60 & 0.43 & 0.61 \\
\hline Euphorbiaceae & Croton floribundus Spreng. & 24.7 & 19.7 & 11.0 & 12.9 & 9.6 & 7.0 & 0.38 & 0.39 & 0.35 \\
\hline Anacardiaceae & Schinus terebinthifolius Raddi & 22.9 & 17.4 & 11.5 & 7.1 & 7.2 & 5.9 & 0.49 & 0.51 & 0.47 \\
\hline Verbenaceae & Citharexylum myrianthum Cham. & 21.7 & 15.0 & 11.4 & 10.7 & 11.0 & 8.7 & 0.40 & 0.35 & 0.38 \\
\hline Fab. Mimosoideae & $\begin{array}{l}\text { Enterolobium contorstisiliquum } \\
\text { Morong }\end{array}$ & 19.7 & 12.8 & 6.7 & 10.1 & 5.2 & 4.9 & 0.31 & 0.28 & 0.23 \\
\hline Tiliaceae & Luehea divaricata Mart. & 16.4 & 11.5 & 7.2 & 7.5 & 6.0 & 5.8 & 0.47 & 0.38 & 0.42 \\
\hline Boraginaceae & Cordia superba Cham. & 14.9 & 9.7 & 4.9 & 7.2 & 6.8 & 5.5 & 0.35 & 0.33 & 0.29 \\
\hline Cecropiaceae & Cecropiapachystachia Trécul & 14.4 & 12.5 & 9.7 & 13.0 & 10.0 & 8.1 & 0.41 & 0.39 & 0.35 \\
\hline Fab. Faboideae & *Lonchocarpus cultratus Vell. & 13.8 & 7.1 & 2.0 & 8.5 & 5.8 & 2.7 & 0.49 & 0.42 & 0.32 \\
\hline Fab. Faboideae & Machaerium stipitatum Vogel & 11.2 & 7.3 & 4.4 & 9.8 & 6.9 & 4.8 & 0.35 & 0.36 & 0.31 \\
\hline Fab. Faboideae & $\begin{array}{l}\text { Centrolobium tomentosum } \\
\text { Guillemin ex Benth }\end{array}$ & 10.9 & 8.6 & 6.4 & 9.9 & 9.5 & 9.7 & 0.54 & 0.52 & 0.39 \\
\hline Fab. Faboideae & Pterogyne nitens Tul. & 9.9 & 6.9 & 3.2 & 8.9 & 5.9 & 4.3 & 0.54 & 0.52 & 0.37 \\
\hline Verbenaceae & *Aloysia virgata Pers. & 8.6 & 7.4 & 3.9 & 9.0 & 8.0 & 4.7 & 0.59 & 0.61 & 0.61 \\
\hline Fab. & Hymenea courbaril Y.T. & 8.0 & 5.7 & 2.6 & 8.0 & 5.4 & 3.3 & 0.54 & 0.53 & 0.54 \\
\hline Caesalpinoideae & Lee\&Langenh & & & & & & & & & \\
\hline Apocynaceae & * Peschiera fuchsiaefolia Miers & 6.8 & 5.0 & 3.1 & 7.0 & 4.6 & 4.1 & 0.38 & 0.39 & 0.35 \\
\hline Fab. Faboideae & Dipteryx alata Vogel & 6.8 & 4.7 & 4.1 & 6.3 & 5.4 & 4.0 & 0.55 & 0.45 & 0.45 \\
\hline Myrtaceae & *1 Psidium guajava L. & 6.0 & 4.7 & 3.4 & 7.0 & 4.6 & 4.9 & 0.53 & 0.50 & 0.48 \\
\hline Myrtaceae & $*^{2}$ Psidium guajava $\mathrm{L}$. & 5.9 & 5.5 & 4.5 & 3.4 & 4.1 & 3.0 & 0.54 & 0.51 & 0.46 \\
\hline
\end{tabular}

${ }^{*}$ Naturally regeneration (not planted) trees.

${ }^{1}$ Understory trees and ${ }^{2}$ open area trees (for $P$. guajava).

for $200 \mathrm{~kg}$ and precision of $50 \mathrm{~g}$. To determine the dry weight of each tree we first estimated the moisture content of each compartment by taking around $2 \mathrm{~kg}$ (fresh weight) of leaves, twigs/branches and roots, and five $3-5 \mathrm{~cm}$ thick disks (one near the base and the others at 25, 50, 75 and $95 \%$ of the stem height) for each stem. Two wedges were taken from each disk, one for determining the moisture content and the other for specific wood density (WD). In the laboratory the fresh samples of leaves, twigs/branches, stems and roots were weighed, ovendried at $70^{\circ} \mathrm{C}$ to constant weight - approximately seven days. The dry weight of individual tree compartments were calculated using fresh weight ratios obtained from these samples. Wood density was analyzed by the Maximum Moisture Content method (Foelkel et al. 1971). The WD for each tree was computed as the arithmetic average of the five discs.

Above and belowground biomass (AGB and BGB) data were subjected to regression analyses, considering as predictor variables the DBH $(\mathrm{cm}), \mathrm{DBH}^{2}\left(\mathrm{~cm}^{2}\right), \mathrm{H}(\mathrm{m})$ and WD $\left(\mathrm{g} \mathrm{cm}^{-3}\right)$. For assessment of goodness of fit of biomass equations four indicators are reported: 1) standard error of parameter estimate of the predictor variables; 2) $P>|t|$, the probability that a $t$ statistic would have a greater absolute value than observed one, given that the true parameter is zero; 3 ) coefficient of variation, computed percent ratio between the standard deviation of the error term divided by sample mean of the dependent variable; and 4) Akaike Information Criterion (AIC; Burnham \& Anderson 2010), based on likelihood and complexity of equation models. Biomass equations having a $t$ value probability $>0.05$ for any predictor variable $\left(\mathrm{DBH}, \mathrm{DBH}^{2}, \mathrm{H}\right.$ and $\left.\mathrm{WD}\right)$ or intercept and biomass equations having coefficient of variation $>70 \%$ were rejected. The equations models were compared using AIC, choosing the best model the one with smaller AIC. AIC's differences less than 10 indicate similarity among models, and AIC's difference greater than 10 indicate difference among models. Graphical analysis of the error of estimated biomass in relation to the observed biomass was used. The correlation of the predictor variables $\mathrm{DBH}^{2}$, WD and $\mathrm{H}$ with the dependent variables $\mathrm{AGB}$ and $\mathrm{BGB}$ were assessed. All analysis were conducted using SAS version 9.2 (SAS Institute 2009) except the AIC that was conducted using R (R Development Core Team 2011).

\section{Results}

The partitioning of dry biomass between the compartments of the 19 tree species evaluated was highly variable, did not show any pattern among species (Figure 1), and was probably due simply to different sizes of the trees (Table 1). From the aggregate data from the 60 trees measured, twigs/branches represented $38 \%$, stems $33 \%$, roots $20 \%$ and leaves only $8 \%$ of total tree biomass $(4,260 \mathrm{~kg})$. The average biomass per tree was $71 \mathrm{Kg}$ (twigs/branches $27 \mathrm{Kg}$, stem $24 \mathrm{Kg}$, roots $14 \mathrm{Kg}$ and leaves $6 \mathrm{Kg}$ ).

The correlation of the predictor variables $\mathrm{DBH}^{2}, \mathrm{WD}$ and $\mathrm{H}$ with the dependent variables AGB and BGB (Figure 2) were higher in the logarithmic models (Figure $2 \mathrm{~g}, 2 \mathrm{~h}, 2 \mathrm{i}, 2 \mathrm{j}, 2 \mathrm{k}$ and 21) than in the arithmetic ones (Figure 2a, 2b, 2c, 2d, 2e and 2f). 


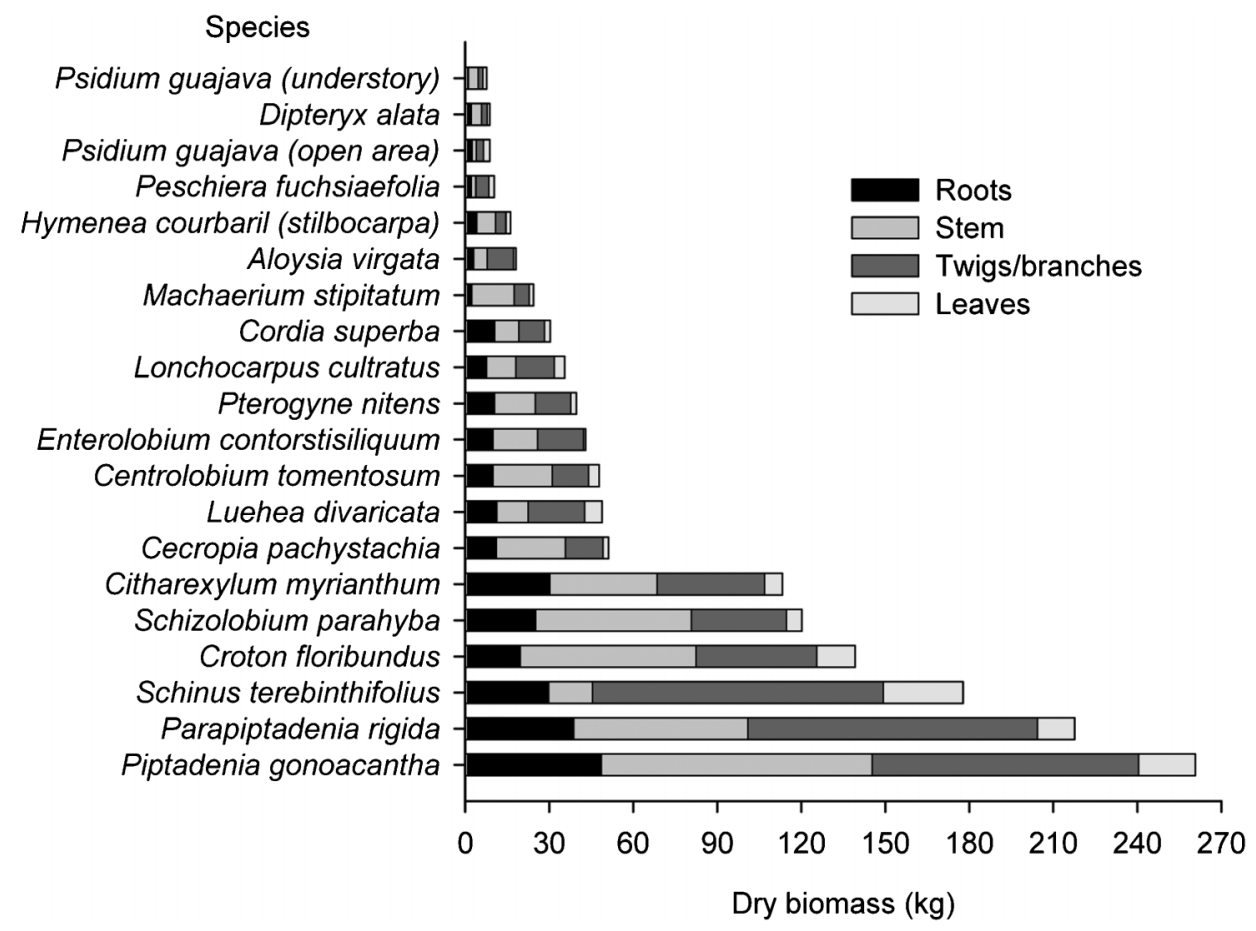

Figure 1. Average tree biomass $(n=3)$ by compartment in 19 species from an experimental area of Atlantic Forest restoration project.

Among the predictor variables $\left(\mathrm{DBH}^{2}, \mathrm{H}\right.$ and $\left.\mathrm{WD}\right)$ the $\mathrm{DBH}^{2}$ had the highest correlation with biomass (AGB and BGB). However, biomass equations using only DBH did not meet the required conditions to be accepted, regarding the arbitrated values of indicators.

For aboveground biomass (AGB) estimates, eight equations models (Table 2) were selected. Equations 4, 5 and 7 were the best fitted, with lower coefficient of variation and AIC. Equations 1 and 2 showed the lowest goodness of fit, with residues not uniformly distributed along the x-axis (Figure 3), mainly for trees $<10 \mathrm{~cm} \mathrm{DBH}$. However, log-transformed equations showed a higher goodness of fit and lower error of estimated biomass. By AIC the best models to AGB were the models 5, 7 and 4, respectively.

For belowground biomass (BGB) estimates, six equation models were selected (Table 2). The log-transformed equations 11 and 13 were the best fitted regarding their lower coefficient of variation, lower error of estimated biomass and lower AIC. Similar to AGB, the untransformed equation (equation 9) led to the lowest goodness of fit, with higher coefficient of variation and AIC value (Table 2). By AIC the best models to BGB were the models 13 and 11 , respectively.

\section{Discussion}

In general, most trees had a higher proportion of twigs/ branch biomass than stem biomass, when compared to other studies undertaken in natural forests that involved a wider range of tree sizes (Chave et al. 2005). Only few species ( $M$. stipitatum, C. tomentosum, C. pachystachia, S. parahyba, $C$. floribundus, $H$. courbaril and D. alata) had a higher proportion of biomass in stem than in other aboveground biomass components. In this experiment, trees were still young, around 11-12 years old, and therefore their architectural development was not completed yet, with poor stem development. Stem biomass will probably increase over time, when the tree individuals increase their DBH as well as WD. Furthermore, since the stands not yet completely stocked, higher availability of light stimulates greater branch development, in contrast to what occurs in more dense natural forests, where stronger light competition reduces branch formation and a higher investment in stem growth. This can be observed by the contrasting biomass allocation of Psidum guajava where trees growing in the understory had a higher proportion of stem than tress growing in full sunlight.

Since average root biomass was $20 \%$, the BGB compartment represents an important component of total stand biomass. Fonseca et al. (2012) found a percentage of $22 \%$ of coarse roots in total tree biomass of native forest plantations in the humid tropical lowlands of Costa Rica. In a New Zealand beech (Nothofagus) forest ecosystem, roots represented $22 \%$ of total live tree biomass (Hart et al.2003). Root biomass or BGB is often expressed as a proportion to AGB, such as a root-shoot ratio ( $\mathrm{R} / \mathrm{S}$ ratio). The $\mathrm{R} / \mathrm{S}$ ratio was 0.25 , similar to forests in tropical zones (0.24, Cairns et al. 1997), montane moist forests (0.22, Sanford \& Cuevas 1996) and New Zealand beech forest ecosystems (0.28, Hart et al. 2003). This indicates that studies focusing only in above ground biomass will be considerably underestimating the capacity of forest to stock carbon in projects that aim at climate change mitigation.

Tree height is well-known as an important indicator of site quality (Teshomea \& Petty 2000) and together with DBH defines the main structural pattern of forest systems. While inclusion of both $\mathrm{DBH}$ and $\mathrm{H}$ in regression equations for biomass estimation is usually recommended (Silveira et al. 2008), in our analysis the use of only $\mathrm{DBH}^{2}$ and $\mathrm{H}$ in equations 6 and 12 led to low goodness of fit, except when WD was included (in equations 5, 8 and 14), reducing the error of estimated biomass. However, the equations 6 and 12 that only use $\mathrm{DBH}^{2}$ and $\mathrm{H}$ as predictor variables is not recommended to 

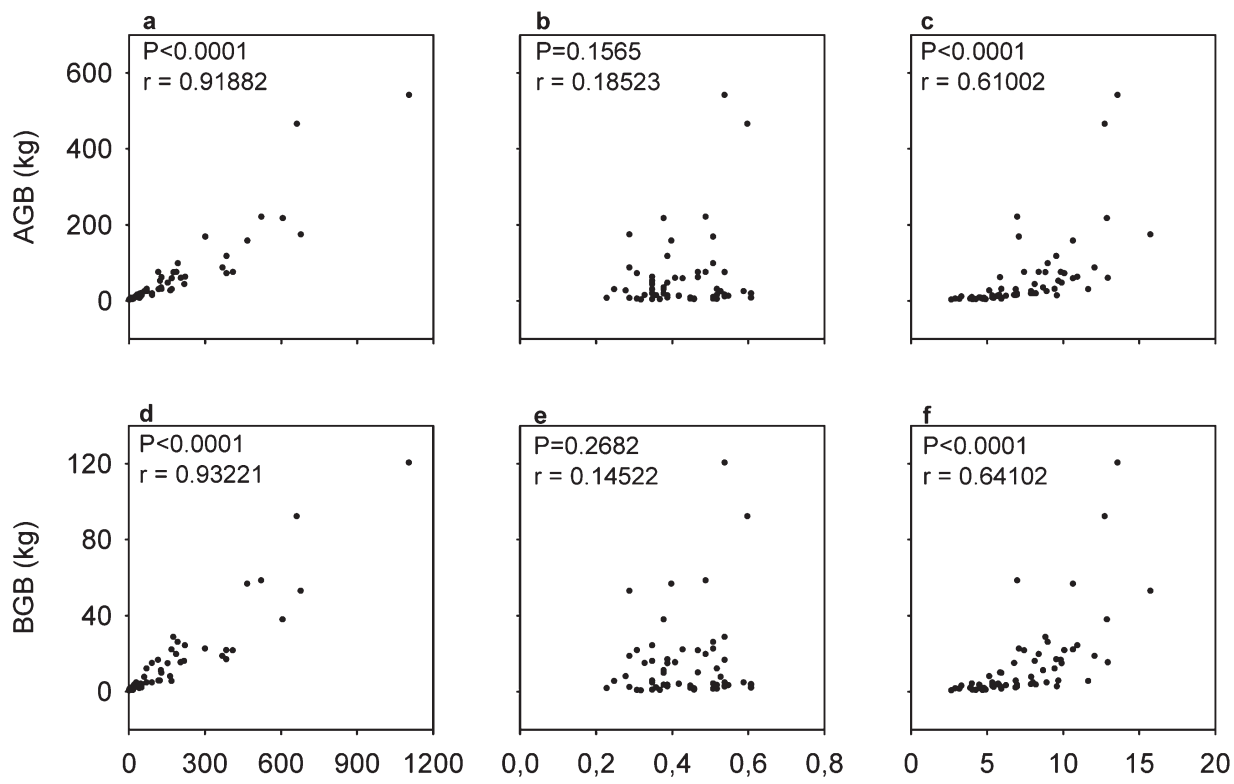

$$
\mathrm{DBH}^{2}\left(\mathrm{~cm}^{2}\right)
$$

$$
\mathrm{SD}\left(\mathrm{g} \mathrm{cm}^{-3}\right)
$$

$H(m)$
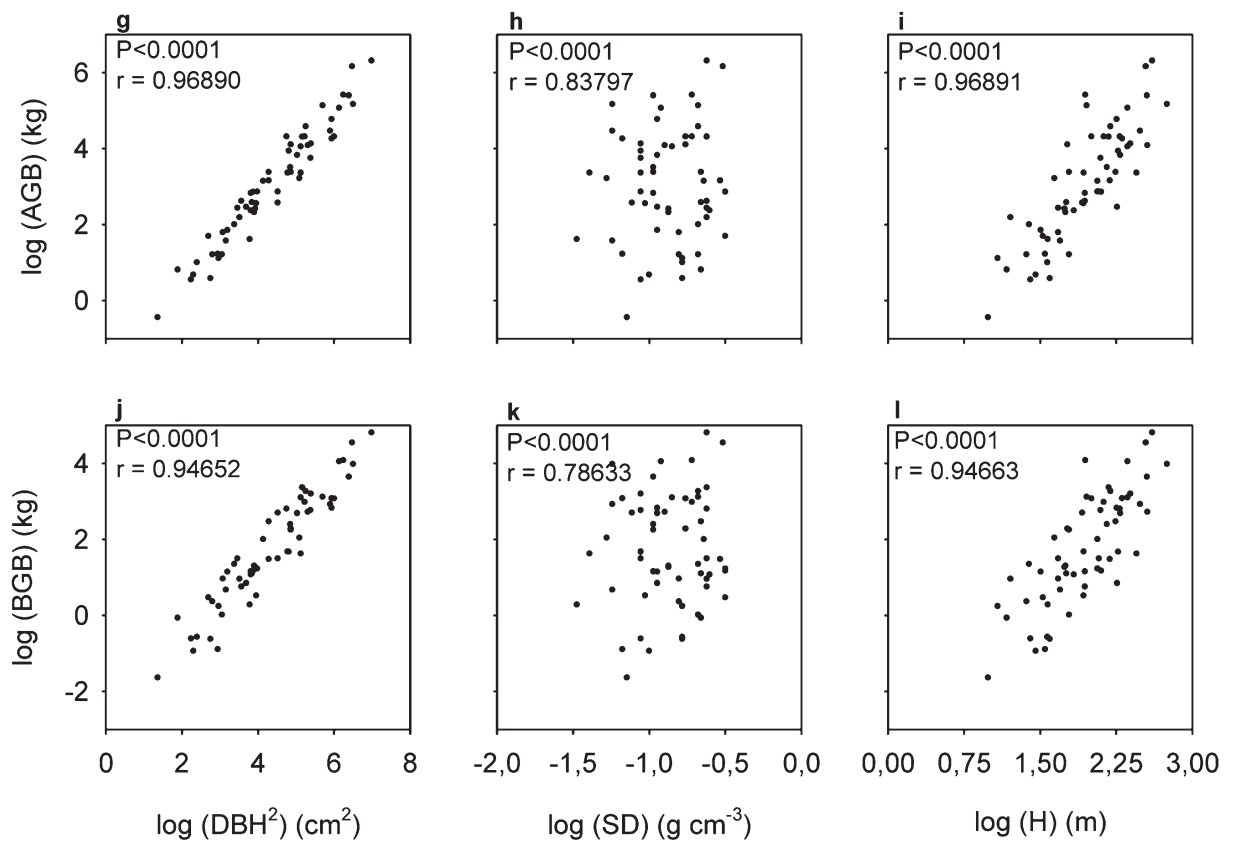

Figure 2. Pearson correlation between predictor variables (DBH, WD and H) and dry biomass (aboveground biomass - AGB and belowground biomass - BGB) for 60 trees of 19 Atlantic Forest species.

biomass estimate because of low goodness of fit.

Only WD correlated [?] with $\mathrm{DBH}^{2}$ (equations 4 and 7 for AGB and equations 11 and 13 for $\mathrm{BGB}$ ) provided good predictions of biomass. This may be attributed to the influence of WD in the variation of dry biomass between species and individuals of different sizes. For example, if only $\mathrm{DBH}^{2}$ and $\mathrm{H}$ are used as predictor variables an underestimation of biomass for small trees having high WD such as $A$ virgata and $P$. guajava and an overestimation of the biomass for large trees having low WD like $S$. parahyba are expected.

Estimates of forest biomass using different equations have led to very contrasting results. In the Brazilian Atlantic Forest, different models produced considerably different biomass estimates (Vieira et al. 2008, Lindner \& Sattler 2012). However, for Vieira et al. 2008 pantropical models of biomass equations (c.f. Chave et al. 2005), using $\mathrm{DBH}^{2}, \mathrm{H}$ and WD as predictor variables may be used to estimate above-ground tree biomass in the Atlantic Forest. Nevertheless, in the present study Chave et al. (2005)'s equation underestimated tree AGB, with an estimation of $1,885 \mathrm{Kg}$. This may be due to the fact that our study included trees with different $\mathrm{DBH}$ and $\mathrm{H}$ ranges (and different tree architectures), with many small individuals in these young forest stands in the early stage of reforestation (low average WD). It should be noted that equations used to estimate biomass, here or anywhere, first need to be based on the appropriate range of tree sizes, and secondarily to the range 


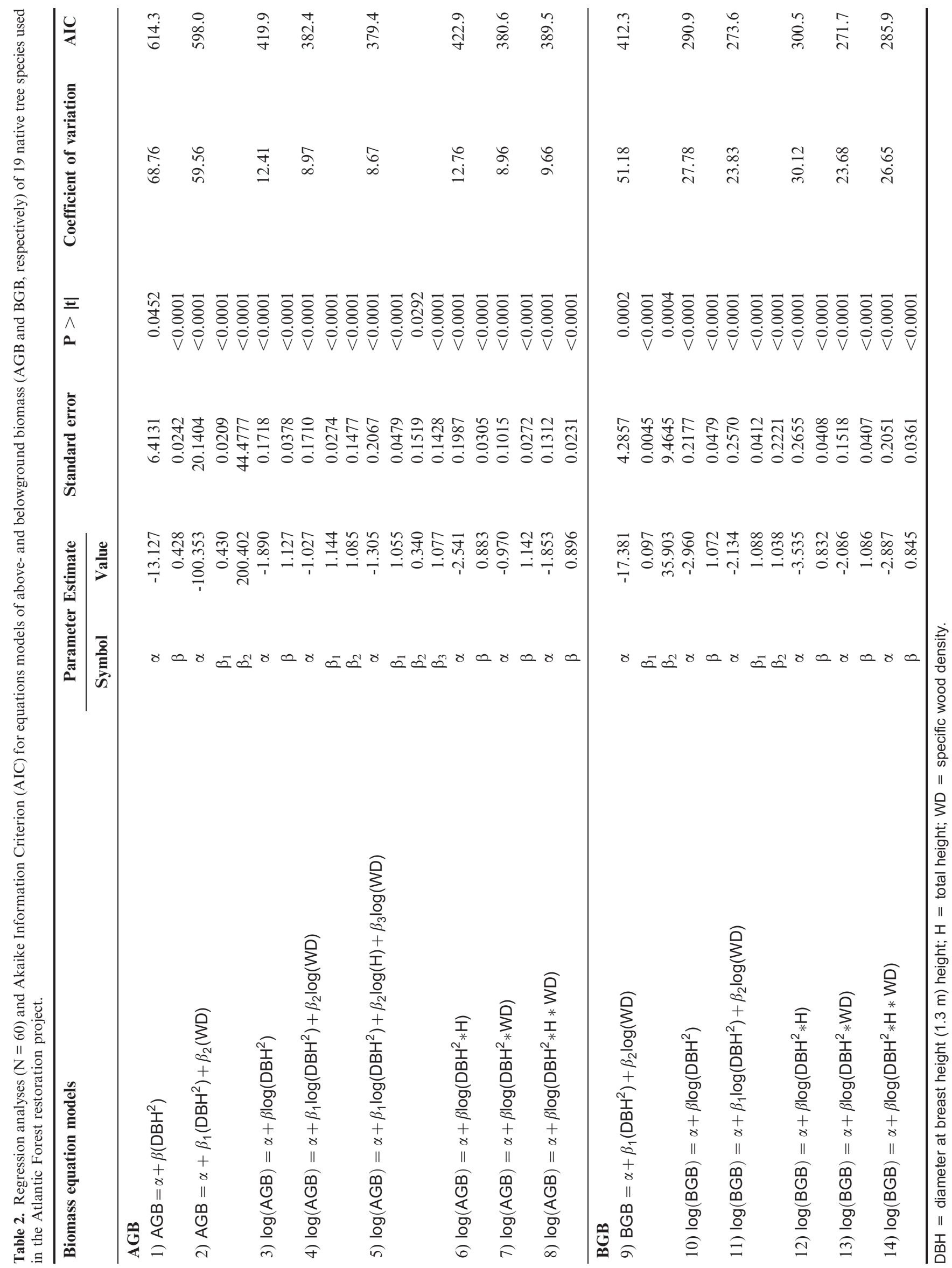



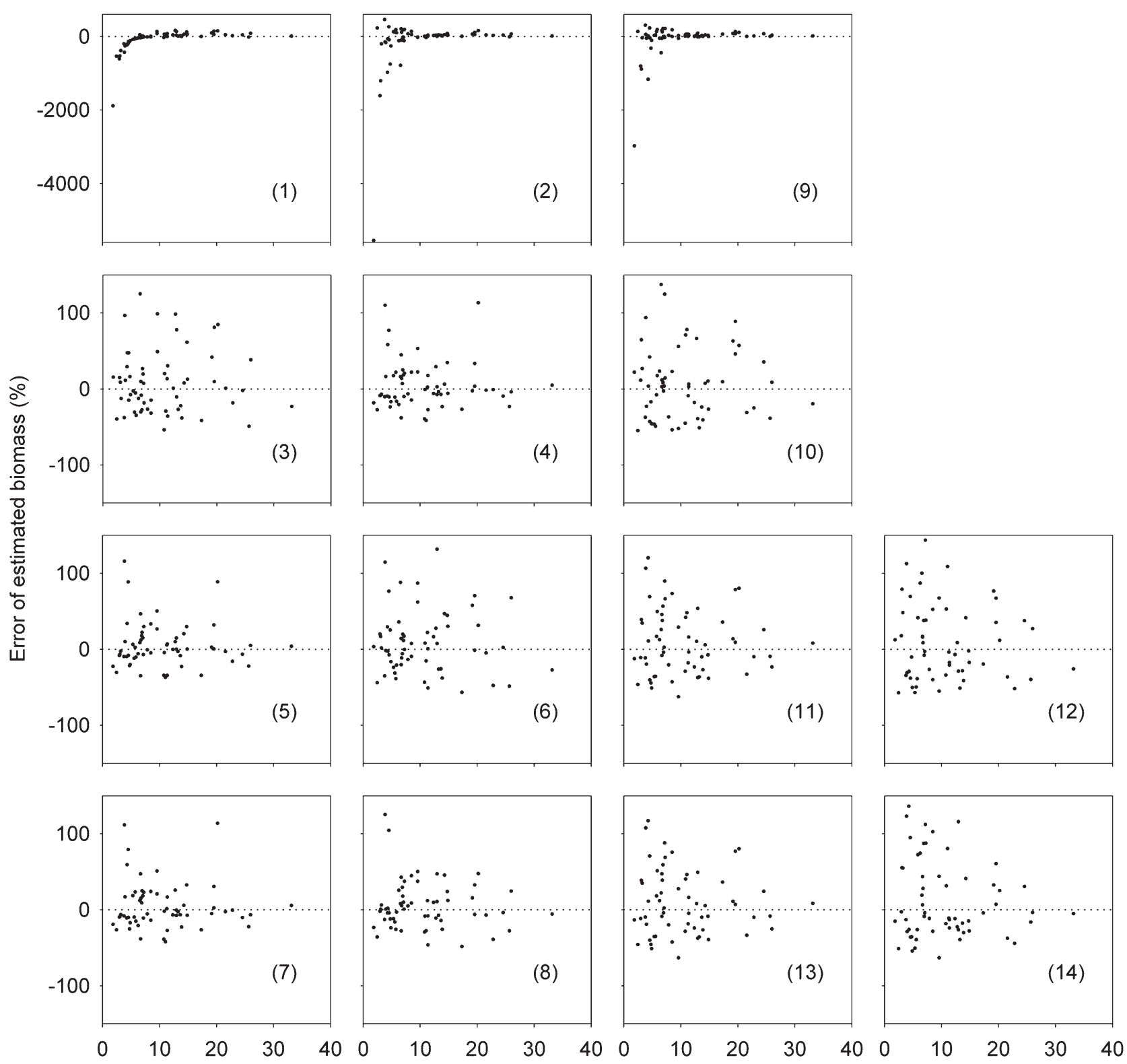

$\mathrm{DBH}(\mathrm{cm})$

Figure 3. Residual analysis (error plots of estimated biomass (\%) by the observed biomass) for 14 equation models trees of 19 Atlantic Forest species. Biomass equation models for above- and belowground biomass (AGB and BGB):(1) AGB $=\alpha+\beta\left(\mathrm{DBH}^{2}\right) ;(2) \mathrm{AGB}=\alpha+\beta_{1}\left(\mathrm{DBH}{ }^{2}\right)+\beta_{2}(\mathrm{WD}) ;(3)$ $\log (\mathrm{AGB})=\alpha+\beta \log \left(\mathrm{DBH}^{2}\right) ; \quad$ (4) $\log (\mathrm{AGB})=\alpha+\beta_{1} \log \left(\mathrm{DBH}^{2}\right)+\beta_{2} \log (\mathrm{WD}) ; \quad$ (5) $\log (\mathrm{AGB})=\alpha+\beta_{1} \log \left(\mathrm{DBH} \mathrm{H}^{2}\right)+\beta_{2} \log (\mathrm{H})+\beta_{3} \log (\mathrm{WD}) ; \quad(6)$ $\log (\mathrm{AGB})=\alpha+\beta \log \left(\mathrm{DBH}^{2} * \mathrm{H}\right) ;(7) \log (\mathrm{AGB})=\alpha+\beta \log \left(\mathrm{DBH}^{2} * \mathrm{WD}\right) ;(8) \log (\mathrm{AGB})=\alpha+\beta \log \left(\mathrm{DBH}^{2} * \mathrm{H} * \mathrm{WD}\right) ;(9) \quad B G B=\alpha+\beta_{1}\left(\mathrm{DBH}{ }^{2}\right)+\beta_{2}(\mathrm{WD}) ;$ $\left(\begin{array}{ll}1 & 0\end{array}\right) \log (\mathrm{BGB})=\alpha+\beta \log \left(\mathrm{DBH}^{2}\right) ; \quad\left(\begin{array}{ll}1 & 1\end{array}\right) \quad \log (\mathrm{BGB})=\alpha+\beta_{1} \log \left(\mathrm{DBH}^{2}\right)+\beta_{2} \log (\mathrm{WD}) ; \quad\left(\begin{array}{ll}1 & 2\end{array}\right) \quad \log (\mathrm{BGB})=\alpha+\beta \log \left(\mathrm{DBH}{ }^{2} * \mathrm{H}\right) ; \quad\left(\begin{array}{ll}1 & 3\end{array}\right)$ $\log (B G B)=\alpha+\beta \log \left(D B H^{2} * W D\right) ;(14) \log (B G B)=\alpha+\beta \log \left(D B H^{2} * H * W D\right)$.

of tree architectural types found in the forest where such equations will be applied.

The sampling error in forest inventory estimates has two main components (Parresol 1999). The first is the component related to random selection of sample units and the second component is associated with the error of the regression model itself. In the present study, the 19 tree species sampled represent more than $95 \%$ of the restoration plots basal area, be in the Control, Direct Seeding and High-Diversity Seedling Plantings. The three harvested individuals of each species represent the range of sizes which were found in the planting sites. Regarding the regression errors they were high for equations 1,2 (for aboveground biomass) and 9 (for belowground biomass), suggesting that the use of untransformed log equations is inadequate to estimate tree biomass in forest plantations.

To reduce the error of estimated biomass the use of logtransformed biomass equations was more appropriated, such as the equation 5 for $\mathrm{AGB}$ and the equation 13 to BGB which had a better goodness of fit. Finally, we concluded that in decrease order the better equations for above- and belowground biomass estimate in restored areas are:

$$
\begin{aligned}
\log (A G B)= & -1.305+1.055 \log \left(\mathrm{DBH}^{2}\right) \\
& +0.34 \log (\mathrm{H})+1.077 \log (\mathrm{WD})
\end{aligned}
$$


$\log (A G B)=-0.970+1.1421 \log \left(\mathrm{DBH}^{2} * \mathrm{WD}\right)$

$\log (A G B)=-1.027+1.144 \log \left(\mathrm{DBH}^{2}\right)+1.085 \log (\mathrm{WD})$

and

$$
\begin{aligned}
& \log (B G B)=-2.086+1.086 \log \left(\mathrm{DBH}^{2} * W D\right) \\
& \log (B G B)=-2.134+1.088 \log \left(\mathrm{DBH}^{2}\right)+1.038 \log (\mathrm{WD})
\end{aligned}
$$

However, log-transformed biomass equations may be only applicable to mixed plantations with tree $\mathrm{DBH}, \mathrm{H}$ and WD ranges similar to the ones showed in Table 1. Provided that there are similarities in species composition, the biomass equations presented here may be useful for application on a local and regional scale. Although these biomass equations may be applied in the context of the Atlantic Forest restoration, for projects focusing on environmental services like carbon sequestration, it is suggested that some tree individuals be evaluated by direct (destructive) method to verify whether the equation to be used overestimates or underestimates tree biomass (Brown 1997).

\section{Conclusions}

The logarithmically-transformed equation that use diameter at breast height, total height and specific wood density as predictor variables are the most accurate equation for estimating above-ground biomass. Furthermore, the logarithmicallytransformed equations that use diameter at breast height and specific wood density as predictor variables showed good accuracy for estimating above- and below-ground biomass. These biomass equations may be recommended for estimating tree biomass in Atlantic Forest restoration projects, providing some similarity in species composition, age or structural development, and site characteristics.

\section{Acknowledgements}

The project received grants from São Paulo Research Foundation (FAPESP) and National Council of Research and Technology (CNPq). The first author received a Ph.D. Scholarship from FAPESP, Process 2006/06315-0. The second author thanks also to $\mathrm{CNPq}$ for the Research Productivity Fellowship. We thank all the students and staff members of the Laboratory of Ecology and Forest Restoration of São Paulo State University (LERF/UNESP) and employees of the Agronomic Sciences College (FCA/UNESP) for field assistance, and in particular Aparecido Agostinho Arruda and Elder Candido Mattos. We also thank A.V. Teodoro (Brazilian Agricultural Research Corporation - Embrapa) for comments on previous versions of the manuscript.

\section{References}

BROWN, S., GILlESPIE, A. \& LUGO A. 1989. Biomass estimation methods for tropical forests with applications to forest inventory data. Forest Science 35: 881-902.

BROWN, S. 1997. Estimating biomass and biomass change of tropical forest: a primer. FAO Forestry Paper - 134, Rome.

BURNHAM, K.P. \& ANDERSON, D.R. 2010. Information and likelihood theory: A basis for model selection and inference.In Model selection and multimodel inference: A practical informationtheoretic approach (K.P. Burnham \& D.R. Anderson, eds). Springer Science, New York, $2^{\text {nd }}$ ed, chap 2, pp 49-97.
CAIRNS, M.A., BROWN, S., HELMER, E.H. \& BAUMGARDNER, G.A. 1997. Root biomass allocation in the world's upland forests. Oecologia 111: 1-11.

CALMON, M., BRANCALION, P., PAESE, A., ARONSON, J., CASTRO, P., DA SILVA, S \& RODRIGUES, R. 2011. Emerging Threats and Opportunities for Large-Scale Ecological Restoration in the Atlantic Forest of Brazil. Restoration Ecology 19: 154-158.

CHAVE, J., ANDALO, C., BROWN, S., CAIRNS, M., CHAMBERS, J., EAMUS, D., FOLSTER, H., FROMARD, F., HIGUCHI, N., KIRA, T., LESCURE, J., NELSON, B., OGAWA, H., PUIG, H., RIERA, B. \& YAMAKURA, T. 2005. Tree allometry and improved estimation of carbon stocks and balance in tropical forests. Oecologia 145: 87-99.

CLARK, D., BROWN, S., KICKLIGHTER, D., CHAMBERS, J., THOMLINSON, J. \& NI, J. 2001. Measuring net primary production in forests: Concepts and field methods. Ecological Applications 11: 356-370.

COLE, T. \& EWEL, J. 2006. Allometric equations for four valuable tropical tree species. Forest Ecology and Management 229: 351-360.

DIXON, R., BROWN, S., HOUGHTON, R., SOLOMON, A., TREXLER, M. \& WISNIEWSKI, J. 1994. Carbon pools and flux of global forest ecosystems. Science 263: 185-190.

ENGEL, V. \& PARROTTA, J. 2001. An evaluation of direct seeding for reforestation of degraded lands in central Sao Paulo state, Brazil. Forest Ecology and Management 152: 169-181.

FOELKEL, C., BRASIL, M. \& BARRICHELO, L. 1971. Métodos para determinação da densidade básica de cavacos para coníferas e folhosas. IPEF 2/3:65-74.

FONSECA, W., ALICE, F.E. \& REY-BENAYAS,J. 2012. Carbon accumulation in aboveground and belowground biomass and soil of different age native forest plantations in the humid tropical lowlands of Costa Rica. New Forests 43: 197-211.

GRACE, J. 2004. Understanding and managing the global carbon cycle. Journal of Ecology 92: 189-202.

HART, P., CLINTON, P., ALLEN, R., NORDMEYER, A. \&, EVANS, G. 2003. Biomass and macro-nutrients (above- and below-ground) in a New Zealand beech (Nothofagus) forest ecosystem: implications for carbon storage and sustainable forest management. Forest Ecology and Management 174: 281-294.

LAL, R. 2005. Forest soils and carbon sequestration. Forest Ecology and Management 220: 242-258.

LINDNER, A. \& SATTLER, D. 2012. Biomass estimations in forests of different disturbance history in the Atlantic Forest of Rio de Janeiro, Brazil. New Forests 43: 287-301.

MASERA, O., GARZA-CALIGARIS, J., KANNINEN, M., KARJALAINEN, T., LISKI, J., NABUURS, G., PUSSINEN, A., DE JONG, B \& MOHREN, G. 2003. Modeling carbon sequestration in afforestation, agroforestry and forest management projects: the CO2FIX V.2 approach. Ecological Modelling 164: 177-199.

MELO, A. \&DURIGAN, G. 2006. Fixação de carbono em reflorestamentos de matas ciliares no Vale do Paranapanema, SP, Brasil. Scientia Forestalis 71: 149-154.

MIRANDA, D.,MELO, A. \&SANQUETTA, C. 2011. Equações alométricas para estimativa de biomassa e carbono em árvores de reflorestamentos de restauração. Revista Árvore 35: 679-689.

NAEEM, S., BUNKER, D., HECTOR, A., LOREAU, M. \& PERRINGS, C. 2009. Biodiversity, ecosystem functioning and human wellbeing: An ecological and economic perspective. Oxford: Oxford University Press, 384p.

NELSON, B., MESQUITA, R., PEREIRA, J., DE SOUZA, S, BATISTA, G \& COUTO, L. 1999. Allometric regressions for improved estimate of secondary forest biomass in the central Amazon. Forest Ecology and Management 117: 149-167.

NOGUEIRA JR, L, GONÇALVES, J, ENGEL, V \& PARROTTA, J. 2011. Soil dynamics and carbon stocks 10 years after restoration of degraded land using Atlantic Forest tree species. Forest Systems 20: 536-545. 
OVERMAN, J., WITTE, H. \& SALDARRIAGA, J. 1994. Evaluation of regression models for above-ground biomass determination in Amazon rainforest. Journal of Tropical Ecology 10:207-218.

PARRESOL, B. 1999. Assessing tree and stand biomass: A review with examples and critical comparisons. Forest Science 45: 573-593.

RODRIGUES, R., GANDOLFI, S., NAVE, A., ARONSON, J., BARRETO, T., VIDAL, C. \& BRANCALION, P. 2011. Largescale ecological restoration of high-diversity tropical forests in SE Brazil. Forest Ecology and Management 261: 1605-1613.

RODRIGUES, R., LIMA, R., GANDOLFI, S. \& NAVE, A. 2009. On the restoration of high diversity forests: 30 years of experience in the Brazilian Atlantic Forest. Biological Conservation 142: 1242-1251.

SALDARRIAGA, J., WEST, D., THARP, M. \& UHL, C. 1988. Longterm chronosequence of forest succession in the upper Rio Negro of Colombia and Venezuela. Journal of Ecology 76: 938-958.

SANFORD JR, R \& CUEVAS, E. 1996. Root growth and rhizosphere interactions in tropical forests.In Tropical forest plant ecophysiology(S. Mulkey, R. Chazdon \& A. Smith, eds). Chapman and Hall, New York, pp 268-300.

SAS INSTITUTE. 2009. SAS $^{\circledR}$ 9.2: qualification tools users guide.
Cary.

SIDDIQUE, I., ENGEL, V., PARROTTA, J., LAMB, D., NARDoto, G., OMETTO, J., MARTINELli, L. \& SCHMIDT, S. 2008. Dominance of legume trees alters nutrient relations in mixed species forest restoration plantings within seven years. Biogeochemistry 88: 89-101.

SILVEIRA, P., KOEHLER, H., SANQUETTA, C. \& ARCE, J. 2008. $O$ estado da arte na estimativa de biomassa e carbono em formações florestais. Floresta 38: 185-205.

TESHOMEA, T. \& PETTY, J. 2000. Site index equation for Cupressus lusitanica stands in Munessa forest, Ethiopia. Forest Ecology and Management126: 339-347.

VIEIRA, S., ALVES, L., AIDAR, M., ARAÚJO, L., BAKER, T., BATISTA, J., CAMPOS, M., CAMARGO, P., CHAVE, J., DELITTI, W., HIGUCHI, N., HONÓRIO, E., JOLY, C., KELLER, M., MARTINELLI, L., MATTOS, E., METZKER, T., PHILliPS, O., SANTOS, F., SHIMABUKURO, M., SILVEIRA, M., \& TRUMBORE, S. 2008. Estimation of biomass and carbon stocks: the case of the Atlantic Forest. Biota Neotropica 8(2): 21-29. 